\title{
Impact of Sustainable Construction on Environmental and Health Risk in Nigerian Construction Industry
}

\author{
Nnadi Ejiofor ${ }^{1}$, Alintah-Abel Uchechi ${ }^{1}$, Iheama Ndidi ${ }^{2}$ \\ ${ }^{1}$ Quantity Surveying Department, Faculty of Environmental, Enugu State University of Science \& Technology (ESUT), Enugu, Nigeria \\ ${ }^{2}$ Building Department, Faculty of Environmental Sciences, Imo State University, Owerri, Nigeria
}

Email address:

ezekiel.nnadi@esut.edu.ng (N. Ejiofor)

\section{To cite this article:}

Nnadi Ejiofor, Alintah-Abel Uchechi, Iheama Ndidi. Impact of Sustainable Construction on Environmental and Health Risk in Nigerian Construction Industry. Journal of Civil, Construction and Environmental Engineering. Vol. 3, No. 4, 2018, pp. 99-105.

doi: $10.11648 /$ j.jccee.20180304.11

Received: January 21, 2018; Accepted: August 8, 2018; Published: September 5, 2018

\begin{abstract}
Construction workers are exposed to a variety of health hazards every day. Health risks associated with a job are either inherent or created by the work. These construction health risks can be classified as chemical, physical, biological hazards. Construction stakeholders are obligated to anticipate, recognize, evaluate and control health hazards at the course of operation. Meanwhile, healthy workforce will give birth to healthy industry. This work aim at determine the key health and environmental risks brought by construction activities; its impact and mitigating mechanisms. Questionnaire was used to sample the opinion of the construction workers and professionals. The data collected was analysed using mean weighted value and presented in a table. Identified health risks in construction includes; lung diseases, haring loss, skin irritation and rashes, cumulative trauma disorders, cancer, lifetime disability and occasionally fatality. Meanwhile, effective site planning, layout and management identified under physical categorization was ranked first as a sustainable safety mechanism with a mean of 4.32 followed by usage of protective wears with a mean score of 4.01. Sound health that reduces sickness on-the-job thereby preventing absenteeism was highest mean score of 4.48 was identified as the major impact of sustainable health followed by cost saving with a mean score of 4.22. The work therefore recommended collaboration between health workers and the industry as well as health and safety training for all construction companies.
\end{abstract}

Keywords: Construction Industry, Environment, Health, Safety, Sustainability

\section{Introduction}

Healthy labour produces a healthy industry. Risk involved in construction activities over the years has brought about a lot of sickness, infections, deformation and death to construction workers. Some of these hazards are cause by biological factors, handling of chemical and physical materials on site and so on. Efforts have been geared in recent years in reducing the number and rate of injuries to construction workers. However, several serious ill-health issues continue to affect construction workers. These can be devastating for individuals, the families and the industry. The built environment inherently affects and contributes to the way in which we live our lives, including health, safety, and quality of the surrounding environment. Construction industry is an important part of the economy in many countries and often seen as a driver of economic growth especially in developing countries. The construction activity in Nigeria represents a significant share of the country's economy in terms of its contribution to GDP and total employment. In addition, it is an important market for materials and products produced by other sectors of the economy [1]. Despite its importance, construction industry is considered as being risky with frequent and high accidents rate and ill-health problems to workers, practitioners and end user [2]. The construction industry is arguably one of the most resource-intensive and environmentally damaging industries in the world. The industry's environmental impacts are more tangible and readily quantifiable than many of the social and macro-economic impacts of the built environmental [3]. Although, Nigeria is enjoying relatively strong growth in construction activities, efforts towards ensuring improved safety performance have yielded minimal results. The enforcement of safety regulations is not 
widespread within the industry. More construction workers are killed injured or suffers ill health than in any other industry. It is however, disheartening that despite several efforts towards improving the health and safety status of Nigeria construction industry, continuous increases in the number of accidents both reported and unreported on construction sites still go unabated. Furthermore, Nigeria has a very high accident record attributable to lack of effective monitoring, reporting and control practices. Added to this problem is the incessant collapse of building in the country which has made safety record to continued being one of the poorest. [4], believes that improving occupational safety and health (OSH) in the construction industry is a slow but achievable process. Thus, occupational health and safety in construction work should start at the designing table and continue throughout the construction phases until the safety and health of end users is ensured due to the complexity of the industry and the hazards it contains [5]. Environmental and health management therefore deals with actions that managers at all levels can take to create an organizational setting in which workers will be trained and motivated to perform safe and productive construction work. The system should delineate responsibilities and accountabilities. It should also outline procedures for eliminating hazards and identifying potential hazards before they become the contributing factors to unfortunate accidents. [6], view sustainable development that "humanity can make development sustainable to ensure that it meets the needs of the present without compromising ability of future generations to meet their own needs". It then identified three global metrics to measure sustainable development. These metrics (Key Performance Indicators - KPIs) include: economy, society and environment (triple bottom line). The three dimensions are often expressed in terms of different broad areas of concerns: Techno-Centric, Eco-Centric, and Socio-Centric. This paper would be limited to the Eco-centric concerns which focus on environmental aspects and the ability of the planet to sustain human beings through the provision of material and energy resources. It also addresses how the ecosystem maintains a state of punctuated equilibrium, by accommodating the emissions and wastes that living organisms (especially human beings) generate through various consumption patterns and economic activities. It considers the effect of construction activities (wastes products and emissions) on the health and the environment. With this context in mind, the research conducted during this study aimed to determine what mechanisms and institutions exist to protect construction site workers from unhealthy or unsafe working conditions and the society by ensuring sustainability in construction. The aim of this research was to determine the key health and environmental risks brought by construction activities; its impact and mitigating or protection mechanisms.

\section{Method}

\subsection{Health Risk and Construction Industry}

Many informal jobs are not only "flexible, precarious and insecure," but are also hazardous and take place in settings which are both unhealthy and unsafe. The workers are expose to environmental disease, traffic accidents, fire hazards, crime and assault, weather related discomfort, and musculoskeletal injuries [7]. Despite the clear risks involved in informal work, due to its unconventional nature and location, informal workers in Nigeria are not protected. It is pertinent therefore that works are carried out as it should to prevent hazard during and after construction. Despite the abundance of health and safety risks in construction industry, the attention been paid to the risk and social protection of workers and product's users are insufficient. Some of the health and safety risks identified in the industry are listed in table 1. These factors are grouped into different headings such as physical, chemical, biological and legislation and rules.

Table 1. Classes of identified sources of health risk in construction industry.

\begin{tabular}{llll}
\hline Chemical & Physical & Biological & Legislation \\
\hline hazardous chemicals & Loud noise & Bacteria & Lack of insurance \\
Vapours & Burn/ Hot work & Poisonous \& Infectious Animals & Poor or no environment impact assessment \\
Fumes & Unsanitary conditions & Contaminated soil conditions & Unimplemented safety and health policies \\
Dusts & Extreme temperatures & Fungi (Mould) & Unavailability of first aids \\
Radiological exposures & Fall & Harmful micro organisms & No medical personnel \\
Fibres & Cumulative Trauma Disorders & Blood borne Pathogens & Ignorance \\
Mists & & Poisonous Plants & \\
\hline
\end{tabular}

Source: Nnadi \& Alintah-Abel, 2017

It is pertinent therefore for construction companies and regulatory bodies to abate hazard in the industry. To abate a hazard means to eliminate its affects; this would cause a worker who might otherwise be exposed to a hazard not be exposed by means of one or more control strategy. These control strategies are chosen by preference in hierarchy of controls. Implementing control strategies, such as engineering controls, safe work practices and wearing personal protective equipment will mitigate health hazards in construction.

\subsection{Concept of Sustainable Construction}

Sustainable development and sustainable construction are intertwined. To understand sustainable construction there is a need to develop an understanding for sustainable development. "Sustainable development is development that 
meets the needs of the present without compromising the ability of future generation to meet their own needs"[8]. The fundamental concept of sustainable construction is to deliver long term affordability, quality and efficiency, value to clients and users, whilst decreasing negative environmental impacts and increasing the economic sustainability [9]. Sustainable construction aims to meet present day needs for housing, working environments and infrastructure without compromising the ability of future generations to meet their own needs in times to come. It incorporates elements of economic efficiency, environmental performance and social responsibility-and contributes to the greatest extent when architectural quality, technical innovation and transferability are included. It is the construction that tows towards the principles of sustainable development. In construction practice, sustainable construction refers to the different method used in the construction project which bring less harm to the environment, benefit the society and increase profit of the company [10]. Sustainable construction involves issues such as the design and management of buildings; materials performance; construction technology and processes; energy and resource efficiency in building, operation and maintenance; robust products and technologies; long-term monitoring; adherence to ethical standards; socially-viable environments; stakeholder participation; occupational health and safety and working conditions; innovative financing models; improvement to existing contextual conditions; interdependencies of landscape, infrastructure, urban fabric and architecture; flexibility in building use, function and change; and the dissemination of knowledge in related academic, technical and social contexts. The construction stage of a building lifecycle is a very dynamic stage with several activities on the job site that involve materials, workers, and moving and handling equipment. These construction activities should be sustainable and at the same time be safe for workers. Although many countries have construction safety and health regulations as well as green building rating systems (including for construction), they are not integrated: each has its own separate procedures and regulating institutions.

This research aims to review the available literature related to construction sustainability and construction worker safety and health. [11], mentioned main principles of sustainable construction such as: maximisation of resource reuse; minimisation of resource consumption; use of renewable and recyclable resources; protection of the natural environment; creation of a healthy and non-toxic environment; and creation of quality in built environments. Sustainable construction embraces three main dimensions namely social, economic and environmental in contrast with the traditional perspective, where the main concerns were economy, utility, and durability. The social dimension addresses issues pertaining to the enhancement of people's quality of life. The economic dimension addresses economics issues such as employment creation, competitiveness enhancement, lower operating/maintenance costs, employment creation, high quality of working environment leading to greater productivity and many others. The environmental dimension deals with the design, construction, operation/maintenance and deconstruction approaches that minimize the adverse impacts on the environment such as air emissions, waste discharges, use of water resources, land use, and others. Design and construction practices that significantly reduce or eliminate the negative impact of buildings on the environment and occupants in five broad areas are generally accepted as green building. These five areas are: Sustainable site planning, Safeguarding water and water efficiency, Energy efficiency and renewable energy, Conservation materials and resources, and Indoor environmental quality.

\subsection{Health and Safety Measures in Construction}

There are two key issues to consider with regards to health and safety in the construction industry as opined by [12]. The first one is respecting people's rights to be protected against risks that affect their safety and long-term health. The second one is that construction sites that are effectively planned and managed are more productive and profitable as well as being safe. The starting point for health and safety is effective planning of construction works. This starts at the design stage by providing the appropriate framework. The design process should involve a detailed assessment of the construction process to make sure that no problematic health and safety issues are inherent within the design. Next is the detailed planning and scheduling. This should include clearly identifying processes for the execution of each element of the works. Finally, is the organising and controlling of works on site. In preparation for this it is necessary to ensure that the people who are working on the site are: Properly trained and competent to do the work safely; Have proper supervision and are given clear instructions and guidance; provided with the right tools, equipment and protective clothing and have and understanding and knowledge of the health and safety issues. Some basic safety principles to be adopted in construction industry include:

Site Layout and Planning: A badly planned and untidy site is the underlying cause of many accidents. This results from falls of material and collisions between workers and plant or equipment. Space constraints, is always rampart as a result proper planning by management is an essential part of preparation and budgeting for the safe and efficient running of a construction operation.

Personal Protective Clothing (PPE): This refers to protective clothing, helmets, goggles, or other garment or equipment designed to protect the wearer's body from injury by blunt impacts, electrical hazards, heat, chemicals, and infection, for job-related occupational health and safety purposes. [13], requires the use of personal protective equipment (PPE) to reduce employee exposure to hazards when engineering and administrative controls are not feasible or effective in reducing these exposures to acceptable levels. This entails construction workers on the sites wearing appropriate protective gear such as helmets, masks, ear muffs, goggles and overalls.

First aid Kits and Accident Reporting: Construction sites 
are dangerous places, and first aid and rescue equipment should always be available. What is needed depends on the size of the site and the numbers employed, but there should be a blanket and a stretcher. On large sites with more than 200 people are employed, there should be a properly equipped first aid room. On any construction site of that size, at least one person on every shift should have been trained in first aid to a nationally recognized standard. On day -to-day works procedures, an accident register book should be kept at the site, in which all types of minor injury such as bruises, to major accidents like imputing disability and fatal should be recorded.

\subsection{Health and Safety Risk Assessment}

Health and safety risk assessment in a construction site is an important measure towards reduction of hazards and injuries. In the context of health and safety, Common definitions used for risk are that: risk is the likelihood of a substance to cause harm; and risk is a combination of the likelihood of an occurrence of a hazardous event or exposure (s) and the severity of injury or ill health that can be caused by the event or exposure. By HSE rules, employers are required to assess the health and safety risks to which employees and others are exposed on construction sites. The significant findings must be recorded where five of more people are employed. Since managing health and safety is different from managing any other aspect in construction there need to do a risk assessment to find out about the risks, and to put sensible measures in place to control them, and make sure they stay controlled. ILO identified chemical Substances are major health hazards since there are many chemicals used in the construction industry, which include insecticides, adhesives, cleaning agents, wood preservatives, fungicides, and paints among others. Many of these chemicals are hazardous, with a potential to cause poisoning. Toxic substances can cause both acute and chronic effects resulting from exposure for a long period. Dusts from many sources are also a prominent hazard in construction. Silica and asbestos dust can permanently damage the lung tissue, whilst lead in dust is absorbed into lungs and enters the blood stream causing poisoning. Cement mixes is also a wellknown cause of skin disease. Lead is found in electricity cables, pipes gutters and lead sheet roofs. Excessive lead absorption causes constipation, abdominal pain, anaemia, weak muscles and kidney failure. Work in the construction industry is tough and involves much manual or physical activity. It is also hazardous and dirty and therefore good welfare facilities not only improve workers' welfare but also enhance efficiency. Welfare facilities such as the provision of drinking-water, washing, sanitary and changing accommodation, rest-rooms and shelter, facilities for preparing and eating meals, temporary housing, assistance in transport from place of residence to the work site and back, all help to reduce fatigue and improve workers' health. Therefore, health and safety measures employed on construction sites are inadequate and fail to meet the required standards. The culture and attitude of construction workers and the site supervisors about health and safety often condone risk taking and unsafe work practices. Lack of proper information and ignorance are also to blame for the poor safety measures in construction sites. For instance some workers felt that the safety equipment such as hard helmets and reinforced boots are too cumbersome and uncomfortable. Most contractors are small and medium enterprises operating within their domestic markets where enforcement of health and safety standards and labour standards is very lax. Enforcement of health and safety regulations remains a problem due to lack of adequate resources available to government institutions responsible for occupational health and safety administration. Also, there remains an acute need for contract provisions to support the enforcement of labour laws in developing countries.

\subsection{Ways of Improving Health and Safety Through Sustainable Development}

There are identified sustainable approaches to health and safety in construction industry such as:

1. Ensuring proper site planning and effective management

2. Reduce the material intensity via substitution technologies

3. Enhance material recyclability

4. Reduce and control the use and dispersion of toxic materials

5. Reduce the energy required for transforming goods and supplying services

6. Support the instruments of international conventions and agreements

7. Maximize the sustainable use of biological and renewable resources

8. Consider the impact of planned projects on air, soil, water, flora, and fauna.

Construction companies should undergo proper training; is competent to do the work safely and be constant training their workers. Having proper supervision with clear instructions and guidance is essential. Workers should be provided with the right tools, equipment and protective clothing. Companies should have an understanding and knowledge of the health and safety issues. Table 2 identified and summarises other recommended practices for safety and health in construction industry.

Table 2. Core Elements of The Recommended Practices for Safety and Health Programs in Construction.

\begin{tabular}{|c|c|}
\hline Management Leadership & $\begin{array}{l}\text {-Top management demonstrates its commitment to eliminating hazards and to continuously improving workplace safety } \\
\text { and health, communicates that commitment to workers, and sets program expectations and responsibilities. } \\
\text {-Managers at all levels make safety and health a core organizational value, establish safety and health goals and } \\
\text { objectives, provide adequate resources and support for the program, and set a good example. }\end{array}$ \\
\hline
\end{tabular}


reporting hazards, investigating incidents, and tracking progress.

-All workers, including contractors and temporary workers, understand their roles and responsibilities under the program and what they need to do to effectively carry them out.

-Workers are encouraged and have means to communicate openly with management and to report safety and health concerns or suggest improvements, without fear of retaliation.

-Any potential barriers or obstacles to worker participation in the program (for example, language, lack of information, or disincentives) are removed or addressed.

-Procedures are put in place to continually identify workplace hazards and evaluate risks.

-Safety and health hazards from routine, non-routine, and emergency situations are identified and assessed.

Hazard Identification and Assessment

Hazard prevention and control

Education and training

Program evaluation and improvement

Communication and Coordination for Employers on Multiemployer Worksites

-An initial assessment of existing hazards, exposures, and control measures is followed by periodic inspections and reassessments, to identify new hazards.

-Any incidents are investigated with the goal of identifying the root causes.

-Identified hazards are prioritized for control.

-Employers and workers cooperate to identify and select methods for eliminating, preventing, or controlling workplace hazards.

-Controls are selected per a hierarchy that uses engineering solutions first, followed by safe work practices, administrative controls, and finally personal protective equipment (PPE).

-A plan is developed that ensures controls are implemented, interim protection is provided, progress is tracked, and the effectiveness of controls is verified.

-All workers are trained to understand how the program works and how to carry out the responsibilities assigned to them under the program.

-Employers, managers, and supervisors receive training on safety concepts and their responsibility for protecting workers' rights and responding to workers' reports and concerns.

-All workers are trained to recognize workplace hazards and to understand the control measures that have been implemented.

-Control measures are periodically evaluated for effectiveness.

-Processes are established to monitor program performance, verify program implementation, and identify program shortcomings and opportunities for improvement.

-Necessary actions are taken to improve the program and overall safety and health performance.

-General contractors, contractors, and staffing agencies commit to providing the same level of safety and health protection to all employees.

-General contractors, contractors, subcontractors, and staffing agencies communicate the hazards present at the worksite and the hazards that work of contract workers may create on site.

-General contractors establish specifications and qualifications for contractors and staffing agencies.

-Prior to beginning work, general contractors, contractors, and staffing agencies coordinate on work planning and scheduling to identify and resolve any conflicts that could impact safety or health.

Source: Recommended Practices for Safety \& Health Programs in Construction, OSHA, 2016

\subsection{Research Methodology}

Due to the exploratory nature of the study, a relatively small data set was used for the statistical treatment of the hypotheses. Questionnaire was designed for the site workers, project managers drawn from construction firms both private and public sectors' operators in south eastern Nigeria. The questions were structured to obtain information on the health issue and challenges encountered on site and the effect of good safety and health on them. Questionnaires were distributed manually and online to the respondents and response personally collected by the researchers. Hundred (100) questionnaires were administered to respondents while sixty-five (65) of these completed questionnaires were used for analysis. The number narrowed down to 65 after the questionnaire were checked for competence and omissions, including errors of multiple answers. The data collected were analyzed using the relative importance index (RII)

$$
\mathrm{RII}=\frac{\sum_{i-1}^{5} \text { ai. mi }}{\sum_{j=1}^{m} x j} \times
$$

Where: $x \mathrm{j}=$ the sum of the $\mathrm{jth}$ factors $1,2,3,4 \ldots \mathrm{M}$;

\section{Result}

\subsection{Methods of Sustainability}

The research identified some sustainability factors that could ensure health and safety in the construction. These factors were grouped as biological, chemical, physical and legal. The results from the findings were ranked and further discussed.

Table 3. Sustainable health and safety measures.

\begin{tabular}{|c|c|c|c|c|c|c|c|c|c|}
\hline & Identified Measures & 5 & 5 & 3 & 2 & 1 & Total & MS & Rank \\
\hline A. & Biological factors & & & & & & & & \\
\hline 1. & Involvement of health personnel & 20 & 17 & 13 & 14 & 1 & 65 & 3.63 & 12 \\
\hline 2. & Treatment and removal of poisonous $\&$ infectious animals & 20 & 26 & 9 & 9 & 1 & 65 & 3.85 & 6 \\
\hline 3. & Treatment of contaminated soil & 17 & 20 & 23 & 4 & 1 & 65 & 3.74 & 8 \\
\hline
\end{tabular}




\begin{tabular}{|c|c|c|c|c|c|c|c|c|c|}
\hline & Identified Measures & 5 & 5 & 3 & 2 & 1 & Total & MS & Rank \\
\hline 4 & Surface treatment from harmful micro organisms & 8 & 23 & 15 & 16 & 3 & 65 & 3.26 & 14 \\
\hline 5 & Usage of disinfectant & 17 & 20 & 23 & 4 & 1 & 65 & 3.74 & 8 \\
\hline B. & Chemical & & & & & & & & \\
\hline 6. & Proper treatment and disposal of hazardous chemicals & 12 & 22 & 17 & 12 & 2 & 65 & 3.74 & 8 \\
\hline 7. & Usage of protective wears & 25 & 24 & 11 & 4 & 1 & 65 & 4.01 & 2 \\
\hline 8. & Avoidance of direct exposure to radioactive elements & 7 & 16 & 20 & 19 & 3 & 65 & 3.08 & 15 \\
\hline C. & Physical & & & & & & & & \\
\hline 9 & Proper placing and positioning of materials and tools & 13 & 41 & 8 & 3 & 0 & 65 & 3.98 & 4 \\
\hline 10 & Usage of protective wears & 25 & 24 & 11 & 4 & 1 & 65 & 4.01 & 2 \\
\hline 11 & Effective site planning, layout and management & 28 & 31 & 5 & 1 & 0 & 65 & 4.32 & 1 \\
\hline 12 & Usage of stable and strong scaffold & 22 & 20 & 15 & 8 & 0 & 65 & 3.86 & 5 \\
\hline $\mathrm{D}$ & Legal \& Regulations & & & & & & & & \\
\hline 13 & Environmental impact assessment & 18 & 27 & 12 & 8 & 0 & 65 & 3.85 & 6 \\
\hline 14 & Strict implementation of health and safety policy & 12 & 22 & 17 & 12 & 2 & 65 & 3.74 & 8 \\
\hline 15 & Ensure site management possession of basic safety training and education & 12 & 11 & 27 & 13 & 2 & 65 & 3.28 & 13 \\
\hline
\end{tabular}

Source: Result of Findings 2018

\subsection{Benefits of Sustainable Construction in the Environment}

Sustainable constructions in the literature promote better ways of doing things for sound health and safety of workers. It also improves the image of the industry. With sustainability, the industry is less risky and thus safer to operate from. Other impact on the workers and the industry are identified and analysed.

Table 4. Positive Impact of sustainability on workers and firms.

\begin{tabular}{|c|c|c|c|c|c|c|c|c|}
\hline Identified positive Rank Impact & 5 & 4 & 3 & 2 & 1 & Total & Mean Score & Rank \\
\hline Sound health and reducing sickness on-the-job & 16 & 31 & 11 & 27 & 0 & 65 & 4.48 & $1^{\text {st }}$ \\
\hline It saves cost by reducing costs associated with workplace accidents and fatalities & 34 & 16 & 11 & 3 & 1 & 65 & 4.22 & $2^{\text {nd }}$ \\
\hline Higher levels of employee productivity & 25 & 30 & 6 & 2 & 2 & 65 & 4.17 & $3^{\text {rd }}$ \\
\hline Ensure effective risk management & 22 & 27 & 10 & 4 & 0 & 65 & 3.94 & $4^{\text {th }}$ \\
\hline Increase confidence and image improvement & 22 & 27 & 10 & 4 & 0 & 65 & 3.94 & $4^{\text {th }}$ \\
\hline Protecting intangible firm assets (e.g. brand image and customer loyalty) & 20 & 29 & 7 & 7 & 2 & 65 & 3.89 & $6^{\text {th }}$ \\
\hline
\end{tabular}

Source: Result of Findings 2018

\section{Discussion}

\subsection{Methods of Sustainability}

From the table 3, effective site planning, layout and management identified under physical categorization was ranked first with a mean of 4.32 followed by usage of protective wears with a mean score of 4.01. Avoidance of direct exposure to radioactive elements and Surface treatment from harmful microorganisms was ranked lowest with a mean score of 3.26 and 3.08 respectively. This shows physical factors are the key causes of health hazard in Nigerian construction environment and the safest means of containing it. This is in agreement with the previous work of [13], which asserts that the use of personal protective equipment (PPE) reduces employee exposure to hazards.

\subsection{Impact of Sustainability on Workers and Firms}

Table 4 shows the positive impact of sustainability on workers. Sound health and reducing sickness on-the-job thereby preventing absenteeism was highest mean score of 4.48 , followed by cost saving with a mean score of 4.22 . It was discovered from findings as shown in table 2 that sustainability has positive impact on workers and construction firms.

\section{Conclusion}

This work has successfully evaluated sustainability in construction and its effect on health and safety of workers and the industry. Poor health and safety measures bring negative effect on the workers such as sickness, accident and fatality. The image of the industry is also negatively affected while loss of confidence is among its effect. Effective planning, site layout and management have been identified as the key sustainable mechanism or control. Also, wearing of protective wears ensure the safety of workers. Meanwhile, EIA assessment, getting health clearance or certificate is essential towards enhancing sound health in the industry. Sustainability construction enhances sound health, less risk, reduces cost and image improvement. Health workers are encouraged to be involved in construction activities. Companies and their staff should be trained on health and safety issues. Government should ensure that health sectors are established in every construction firms with licensed medical and health and safety personnel in charge. Existing health policies should be enforced by government agencies. Insurance on workers should be taken as key to award 
contract while medical check-up at intervals of the workers should be mandatory.

\section{References}

[1] Alintah-Abel, U., and Nnadi, E. O. E (2015). An assessment of foreign construction firms'participation on the cost of construction works in Nigeria. In: Ogunsemi, D. R, Awolede, O. A, \& Oke, A. E (Eds). Proceedings of the $2^{\text {nd }}$ Nigerian Institute of Quantity Surveyors Research Conference Federal University of Technology, Akure (pp 2-13).

[2] Grace. M and Cornelius M. (2014). Health and Safety Management on Construction Project Sites in Kenya. A Case Study of Construction Projects in Nairobi County, FIG Congress 2014.

[3] Israel. O. A. (2005). Sustainable Construction: A Web-Based Performance Assessment Tool. A dissertation thesis submitted in partial fulfilment of the requirements for the award of the degree Doctor of Engineering, at Loughborough University.

[4] Neale. R. (2013). "Ten factors to improve occupational safety and health in construction projects," African Newsletter on Occupational Health and Safety, 23 (3), pp. 52-54. http://www.ttl.fi/africannewsletter.

[5] Kayumba. A. (2013). "Editorial: Construction work and occupational safety and health," African Newsletter on Occupational Health and Safety, 23 (3), p. 51.http://www.ttl.fi/africannewsletter.

[6] Ugwu. O. O (2013) Risk Analysis And Management For
Sustainable Infrastructure Delivery. A Paper At 2-Day National Workshop Organized by The Nigerian Institute Of Quantity Surveyors (NIQS), Enugu State Chapter Between 8th -9th August At Sunshine Guest House, Ebeano, Enugu.

[7] Laura Alfers (2014): Occupational Health \& Safety for Informal, Workers in Ghana A case study of market and street traders in Accra, School of Development Studies, University of KwaZulu-Natal, Durban.

[8] Malik K., Ali N., Tayyab M., Nawaf A and Amrit S. (2015). Perceptions towards Sustainable Construction amongst Construction Contractors in State of Victoria, Australia. Journal of Economics, Business and Management, Vol. 3, No. 10 , October 2015.

[9] Menoka. B., David. B and Daminam. F (2013). Stakeholder Engagement: Achieving sustainability I the construction Sector. Sustainability 6, 695-710 (ISSN 2074-1050) www.mdpi.com/journs1/sustanability.

[10] Shen LY, Tam VWY, Tam L, JI YB (2010) Project feasibility study: the key to successful implementation of sustainable and socially responsible construction management practice. $J$ Clean Prod 18: 254-259.

[11] D (2003) Sustainable construction: challenges and opportunities. In: Greenwood, D J (Ed.), 19th Annual ARCOM Conference, 3-5 September 2003, University of Brighton. Association of Researchers in Construction Management, Vol. 1, 289-97.

[12] Alhajeri, M. (2011) Health and safety in the construction industry: challenges and solutions in the UAE. Unpublished Thesis, Coventry: Coventry University. 